\title{
Criminal Law Violations in Labour Safety at Coal Mining Enterprises
}

\author{
Yury Volgin ${ }^{1 *}$, Irina Gaag $^{2}$, and Alexander Naumov ${ }^{2}$ \\ ${ }^{1}$ Kemerovo State University, 650000, 6 Krasnaya st., Kemerovo, Russia \\ ${ }^{2}$ Plekhanov Russian University of Economics, Kemerovo branch, 650992, 39, Kuznetskiy prospect, \\ Kemerovo, Russia
}

\begin{abstract}
The paper deals with the qualification of criminal violations of safety rules in coal mining enterprises in the light of recent changes in Art. 216 and 217 of the Criminal Code of the Russian Federation, as well as the adoption of a new Resolution of the Plenum of Supreme Court of the Russian Federation on violations of safety rules during operations. Firstly, the old and new editions of Art. 216 and 217 of the Criminal Code are compared. After that, the distinctive features of the articles under consideration are examined with the help of the new Plenum Resolution, federal laws and bylaws. Finally, the case law on this issue has been reviewed since 2016 with consideration of specific examples. In the paper, the authors do not address the issues of qualifying violations of safety rules at coal mining enterprises under Art.143 of the Criminal Code as it has not been changed. At the end of the study, the authors formulate the qualification rules taking into account the latest changes, without proposing any changes to the Criminal Code of the Russian Federation and other regulatory legal acts that do not include the Resolution of the Plenum of the Supreme Court, i.e. the results of the study can be used in practice. The problem is that there is a lack of research of the changes we are considering in the Criminal Code of the Russian Federation, and even more in relation to the coal mining industry.
\end{abstract}

\section{Introduction}

In the Kemerovo region the security at coal mining enterprises is relevant due to a large number of these companies in the region and, accordingly, a large number of violations in the field of security at coal mining enterprises. So, for 2016-2018, as well as for the first 2 months of 2019, in the Kemerovo region, there were more sentences issued for violating the rules when conducting construction or other works (Art.216 of the Criminal Code of the Russian Federation) in the field of coal mining than in the whole Russia for the same period.

In addition, the legal regulation of criminal liability for safety violations and occupational safety requirements has undergone major changes. Firstly, Art.216 of the

\footnotetext{
${ }^{*}$ Corresponding author: volgin384@mail.ru
} 
Criminal Code "Violation of safety rules in construction or other works" was changed. Secondly, Art.217 of the Criminal Code of the Russian Federation, which is now called "Violation of industrial safety requirements of hazardous production facilities", was radically changed too. Thirdly, a new Resolution of the Plenum of the Supreme Court of the Russian Federation No. 41 dated November 29, 2017 "On judicial practice in criminal cases on violations of labor protection requirements, safety rules during construction or other works or industrial safety requirements of hazardous production facilities" (hereinafter Resolution No.41 of the Plenum of the Supreme Court of the Russian Federation of 11/29/2018) was issued instead of the previously in force Resolution No.1 of the Plenum of the Supreme Court of the Russian Federation of 04/24/1991 "On judicial practice in cases of violations of occupational health and safety rules in mining, construction or other works"(hereinafter - the Resolution No.1 of the Plenum of the Supreme Court of 23.04.1991). Fourthly, in recent years, the adoption of new technical legal acts in the field of occupational safety instead of similar old ones has continued.

All these factors, in general, require the study of criminal law safety issues at coal mining enterprises. Unfortunately, this problem is undeveloped, especially against the background of changes in regulatory legal acts. We have already conducted a study on this topic [1], which, however, can no longer be considered relevant for the above reasons.

\section{Materials and methods}

To begin with, we should consider the changes in the Criminal Code related to the subject of the study. The word "mining" was removed from Art.216 of the Criminal Code of the Russian Federation amended on 04.23.2018, and now Art.216 of the Criminal Code provides the liability only for violations of safety rules in construction and other works [2]. At first glance, this change affects nothing, because, according to the meaning, the list of works is not full. However, the edition of Art.217 of the Criminal Code has changed completely. Earlier it provided liability for violation of safety rules at explosive objects or in explosive workshops, even if such a violation could only result in the death of a person, or cause major damage, but according to the current edition of Art.217 of the Criminal Code of the Russian Federation, the responsibility is provided for violation of industrial safety requirements of hazardous production facilities, resulting in serious damage to health or major damage.

Thus, when comparing two editions of Art.217 of the Criminal Code, there are 3 differences:

- the content of Art.217 of the Criminal Code of the Russian Federation became material, i.e. one in which a crime is considered to be completed only upon the occurrence of the consequences provided in the Article (in this case, serious harm to health or major damage). Moreover, now the consequences stipulated by Art.216 and Art.217 of the Criminal Code are identical;

- the crime scene has changed - now these are not explosive objects and explosive workshops, but hazardous production facilities;

- Art.217 of the Criminal Code provides liability for violation of industrial safety requirements, but not just safety rules.

Moreover, in connection with the entry into force of the new Resolution No.4 of the Plenum of the Supreme Court of the Russian Federation of November 29, 2018, it is necessary to compare this document with the Resolution No.1 of the Plenum of the Supreme Court of the Russian Federation of April 23, 1991 in order to identify new developments in criminal law regulating labor protection and safety. 
Since the Resolution of the Plenum of the Supreme Court of the Russian Federation of November 29, 2018 does not consider the difference between Art.216 and Art.217 of the Criminal Code of the Russian Federation, we have to analyze bylaws for this purpose. To solve this problem, it is necessary to consider the concept of hazardous production facilities and industrial safety requirements.

In accordance with clause 5 of Resolution No. 4 of the Plenum of the Supreme Court of the Russian Federation of November 29, 2018, when resolving the issue of classifying a specific production as a dangerous production facility in a criminal case under Art.217 of the Criminal Code of the Russian Federation, courts should be guided by the Federal Law №116-FL "On industrial safety of hazardous production facilities" [3].

This is an important innovation, because the Resolution No.1 of the Plenum of the Supreme Court of the Russian Federation of April 23, 1991 did not clarify how to distinguish between Art.216 and Art.217 of the Criminal Code, which forced to turn to the works of scientists and to the materials of judicial practice. It means that from now when deciding which article of the Criminal Code to apply to each specific case, it is necessary to determine whether this type of work is listed in Federal Law №116-FL of July 21, 1997 "On the industrial safety of hazardous production facilities" (hereinafter the Federal Law No.116-FL, 21.07.1997).

In accordance with clause 5 of the Hazardous production facilities list (Appendix No.1 to the Federal Law No.116-FL of July 21, 1997), hazardous production facilities include facilities that are being mined (with the exception of the extraction of common minerals and the development of placer mineral deposits carried out by the open method without using blasting), work on mineral processing [4].

In clause 8 of the Hazardous production facilities classification, which is Appendix 2 of the mentioned Federal Law, the coal industry mines are directly classified as the 1st hazard class. The objects of coal processing (combustible shale) are referred to the 2 nd hazard class by this legal act, and the objects on which open mining is carried out are referred to the 3rd and 4th hazard classes depending on the volume of mining rock mass on them.

Thus, coal mining facilities in any case belong to hazardous production facilities, therefore, from now crimes that violate safety requirements at coal mining facilities must be classified under Art.217 but not Art.216 of the Criminal Code.

However, the concept of "dangerous production facility" is not identical to the concept of "dangerous working conditions". The concept of dangerous working conditions is described in clause 2.4.9 of National State Standard 12.0.002-2014: Interstate standard, Occupational safety standards system, Terms and definitions (hereinafter - NSS 12.0.0022014). According to this act, these are working conditions in which the exposure of hazardous production factors to working staff, even if the regulated safety measures are observed, is not excluded and, under certain circumstances, can suddenly and unexpectedly for those who work be realized [5]. In accordance with clause 4 of the Labor Code of the Russian Federation (hereinafter referred to as the Labor Code of RF), hazardous production agent is a production factor, the effect of which on an employee can lead to his injury [6]. In this case, a clear distinction between the hazardous production factor and the harmful production factor is made, in accordance with clause 3 of the Labor Code of RF. In contrast to hazardous the harmful production factors cause diseases, and in clause 2.2.24 of NSS 12.0.002-2014 it is noted that harmful production factors can become dangerous.

Thus, the definition of dangerous working conditions depends on the possibility of an industrial injury, and the concept of a hazardous production facility is described as a list in the Federal Law No.116-FL of July 21, 1997, i.e. dangerous works are not limited by those in which there are hazardous production facilities.

Let us consider the concept of "industrial safety" and its relationship with related concepts. In accordance with clause 1 of Art.1 of the Federal Law No.116-FL of 
21.07.1997 industrial safety of hazardous production facilities is a state of protection of the vital interests of an individual and society against accidents at hazardous production facilities and the consequences of these accidents. In accordance with clause 2 of Art. 1 of this Federal Law, an accident is the destruction of structures and (or) technical devices used at a hazardous production facility, an uncontrolled explosion and (or) release of hazardous substances.

The concept of "production safety (safety of production activities)" is described in clause 2.3.7. NSS 12.0.002-2014. According to it, production safety is a type of activity aimed at protecting production against hazards and risks of harm to the production process, property, environment, health and life of workers and third parties. In the footnote to this clause it is said that industrial security of hazardous production facilities is one of the elements of industrial safety (in addition, the concept of industrial safety includes fire safety, explosion safety, transport safety, physical safety of property (securing property from embezzlement), etc.).

Thus, the industrial safety of hazardous production facilities, which is the object of a crime under Art.217 of the Criminal Code of RF, is a narrower concept than industrial safety, which is the object of a crime under Art.216 of the Criminal Code.

Now we turn to the consideration of empirical material.

We analyzed the cases of violation of safety rules at coal mining enterprises considered by the courts of general jurisdiction for the period from 2016 to the end of 2018, as well as the cases considered in early 2019. 29 criminal cases on violation of safety rules at coal mining enterprises were heard in the Russian Federation. Of these, 21 criminal cases were judged in the Siberian Federal District, and 15 criminal cases on the territory of the Kemerovo region.

Among them, there were no one criminal case under Art.143 of the Criminal Code of the Russian Federation ("Violation of labor protection requirements"), and only one criminal case under Art.217 of the Criminal Code. In all other criminal cases, individuals were convicted under Art.216 of the Criminal Code.

Let us consider the sentence in which the person was convicted under Art.217 of the Criminal Code. Underground mine overseer at VTB site Sh.S. ... having received the information about methane gas with concentration level of $67 \%$ in rock bed clusters, with a permissible methane gas concentration of $2 \%$ in rock bed clusters ... doubted in its reliability having no reason for that, and breaking safety rules in mining operations was inactive ... in addition, he allowed the work of strengthening the rock roof using drilling equipment by the workers of the contracting organization.

Underground mining foreman at VTB site K.G... measured the concentration of methane gas in the dome of roof, having set the level of methane gas in a concentration of $4 \%$ in rock bed clusters, with an acceptable level of methane gas concentration of $2 \%$ in rock bed clusters ... was inactive, while he was aware of the social danger of his inaction, foresaw the possibility of socially dangerous consequences, did not want, but deliberately allowed these effects, did not take measures to stop the work carried out in the place of exceeding concentration of methane gas in rock bed clusters... this contributed to the creation of a dangerous situation, in the form of ignition of methane ..., which caused the ignition of the coal mass, which could have socially dangerous consequences in the form of human death [7].

In the considered criminal case, the death of a person or major damage did not occur; however, according to the old version of Art.217 of the Criminal Code of the Russian Federation it is sufficient to create the danger of such consequences.

Now let us consider one of the sentences under Art.216 of the Criminal Code. F.A., working as an underground electrician ... during repair work to determine the cause of the voltage absence on the combine, decided forcibly turn on the combine using a diode, in 
order to determine the integrity of the supply cable ... started the combine directly, eliminating safety interlocks ... After energizing the conveyor electrical equipment of face $\mathrm{N}$ he turned on the transformer station $<$ data taken $>$ without removing the diode set by him to turn on the combine $<$ data taken $>$, as a result of which the unauthorized start of the combine occurred $<$ data taken $>$ and the miner of the clearing face was injured by the upper cutting body (auger) of the combine... . Damage data ... are regarded as serious health damage on the basis of significant permanent loss of total working capacity by at least one third, due to negligence of F.A.A. [8].

In this case, there are consequences in the form of corporal hurt of the injured. In other sentences under Art.216 of the Criminal Code of the Russian Federation there is also grievous bodily harm, death or major damage. In general, as we have previously noted [1], when considering cases of crimes committed in coal mining enterprises, the courts apply Art.216 of the Criminal Code in the presence of one of the above consequences. In their absence, the courts apply Art.217 of the Criminal Code.

Now let us consider as an example a court verdict on violation of safety requirements at a coal mining enterprise after the amendments to the Criminal Code of the Russian Federation came into force and the new Resolution of the Plenum of the Supreme Court of the Russian Federation was adopted.

Sh., having received by phone a work order on the 2 nd shift from the head of the loading department, according to which it is forbidden to start working until the violation of the occupational and industrial safety rules is eliminated, did not stop working at the loading section and did not forbid unloading dump trucks before reducing the height of the coal pile from the actual 9 meters to the permitted not more than 5 meters ..., which led to the collapse of the coal pile site under the rear axle of the mining truck. As a result of the above violations of labor safety requirements and safety regulations made by Sh. at the time of the dump truck tipping and dumping, driver A. suffered bodily injuries ... qualifying as serious bodily harm because of danger to life, by negligence of Sh. $[9,10]$.

In our opinion, the qualification of court is erroneous. In the considered situation there was a collapse of the coal pile, which can be qualified as an accident in accordance with the Federal Law No.116-FL of July 21, 1997, i.e. there was precisely a violation of the industrial safety requirements of hazardous production facilities, so the crime had to be qualified under Part 1 of Art.217 of the Criminal Code, but not under Part 1 of Art.216 of the Criminal Code.

\section{Results and discussion}

If in the previous edition Art.216 and 217 of the Criminal Code of the Russian Federation were differed in the place and structure of crime, then in the current version Art. 216 and 217 of the Criminal Code of the Russian Federation differ in the place and nature of the violated rules.

For Art.216 of the Criminal Code of the Russian Federation the situation is important, i.e. conducting of construction and other works. For Art.217 the place of crime is important, i.e. a dangerous production facility. Moreover, the concept of a hazardous production facility is not equal to the concept of hazardous work, since the criteria for determining a hazardous production facility are established in the Appendix to the Federal Law No.116FL of July 21, 1997. Thus, the works, although they are hazardous (undoubtedly, many works in construction are hazardous) do not necessarily refer to works where there are hazardous production facilities (although in Art.216 of the Criminal Code of the Russian Federation there is no indication of the danger of work, however the fact that in the course of work one can inflict serious bodily harm or death by violating the requirements of safety during the work already speaks about the danger of this work). 
For qualification under Art.216 of the Criminal Code of the Russian Federation it is required the violation of working safety rules, and for qualification under Art.217 of the Criminal Code of the Russian Federation it is required the violation of industrial safety rules of hazardous production facilities, i.e. and on this basis Art.217 of the Criminal Code of the Russian Federation will be more narrow.

Thus, we can conclude that in the current version Art.217 of the Criminal Code is in relation to Art.216 of the Criminal Code of the Russian Federation a special part, i.e. a special case of Art.216 of the Criminal Code. Moreover, the fact that Art.217 of the Criminal Code of the Russian Federation is a special part in relation to Art.216 of the Criminal Code indicates a stricter sanction of Art.217 of the Criminal Code. That is for qualification under Art.217 of the Criminal Code, it is necessary to establish a combination of 2 signs: the crime scene is a hazardous production facility, and the industrial safety rules of hazardous production facilities are violated. In the absence of at least one of the indicated signs, the action must be qualified according to Art.216 of the Criminal Code. It is understood that we also need the evidence of crime, common both for Art.143 and Art.216 of the Criminal Code.

With regard to the coal mining, qualification is simplified, because by law, the objects on which coal mining takes place are classified as hazardous production facilities. Therefore, for proper qualification, it is necessary to establish the nature of the violated rules: whether the industrial safety rules of hazardous production facilities are violated or other safety rules are violated during the conduct of work (e.g. physical property safety rules).

Unfortunately, the Supreme Court did not clarify the delimitation of Art.216 and 217 of the Criminal Code. There are no explanations in the previous Resolution No.1 of the Plenum of the Supreme Court of the Russian Federation of April 23, 1991. This is a major omission of the Supreme Court, taking into account the amended wording of Art. 217 of the Criminal Code of the Russian Federation, because, as practice shows, the courts make mistakes when qualifying crimes committed in coal mining enterprises.

As for the possibility of qualifying violations of safety rules in coal mining enterprises under Art.143 of the Criminal Code, in the format of this article we have no opportunity to consider this matter, although it also requires to be researched.

\section{Conclusion}

Recent changes in the legal regulation of criminal liability for violations in the area of production safety require changes giving clarification on this matter in the Resolution of the Plenum of the Supreme Court. The new Resolution No.41 of the Plenum of the Supreme Court of the Russian Federation of November 29, 2018 does not sufficiently clarify the controversial issues of qualification.

Art.217 of the Criminal Code of the Russian Federation in a new edition is a special part in relation to Art.216 of the Criminal Code. For qualification under Art.217 of the Criminal Code, it is necessary to establish the following signs: the crime scene is a hazardous production facility, and the industrial safety rules of hazardous production facilities are violated. In the absence of at least one of the indicated signs, the action must be qualified according to Art.216 of the Criminal Code.

Coal mining enterprises are legally classified as hazardous production facilities, so Art.216 and 217 of the Criminal Code of the Russian Federation in this branch are differentiated only depending on the nature of violated rules.

Judicial practice has not accepted the changes in Art.216 and 217 of the Criminal Code so far, as a result of which it makes mistakes in qualifying crimes. 


\section{References}

1. M. Agienko, A. Naumov, I. Gaag, Yu. Volgin, E3S Web Conf., 41, 04046 (2018)

2. M. Agienko, Yu. Volgin, E. Moroz, T. Olofinskaya, E3S Web Conf., 41, 02030 (2018)

3. Criminal Code of the Russian Federation by 17.06.1996 (Femida, Moscow, 2018)

4. Resolution of the Plenum of the Supreme Court of the Russian Federation No. 41 dated November 29, 2018 "On judicial practice in criminal cases on violations of labor protection requirements and safety rules when conducting construction or other works or industrial safety requirements of hazardous production facilities" (Supreme Court of Russian Federation, Moscow, 2019)

5. Federal Law of 21.07.1997 No. 116-FZ “On Industrial Safety of Hazardous Production Facilities" (Collection of Legislation of the Russian Federation, Moscow, 1997)

6. State Technical Standard Occupational safety standards system. Terms and definitions (Standard Inform, Moscow, 2016)

7. Labour Code of Russian Federation (Law Collection of Russian Federation, Moscow, 2002)

8. The verdict of Leninsk-Kuznetsky city court of the Kemerovo region dated 10.10.2016 in case No. 1-55 /2015 (ATP Consultant Plus Moscow, 2019)

9. The verdict of the Berezovsky city court of the Kemerovo region dated October 31, 2016 in case No. 1-188/2016 (ATP Consultant Plus Moscow, 2019)

10. The verdict of the Prokopevsky District Court of the Kemerovo Region dated February 21, 201 in case No. 1-33/2019 (ATP Consultant Plus Moscow, 2019) 